ORIGINAL ARTICLE / ARTIGO ORIGINAL

HIV/AIDS epidemic in a western border municipality of Rio Grande do Sul, Brazil: evolution, HIV cascade of care and lethality

\title{
Epidemia de HIV / aids em município da fronteira oeste do Rio Grande do Sul, Brasil: evolução, cascata de cuidados e letalidade
}

\author{
Rosane Silvia Davoglio' (D), Henrique Gandin" (D), Lucas Pitrez Mocellin"
}

ABSTRACT: Objective: To analyze the characteristics and trends of HIV/AIDS epidemic in Uruguaiana, Rio Grande do Sul, between 2005 and 2015 through indicators related to infection and the cascade of care of people living with HIV/AIDS (PLWHA). Methods: Descriptive study performed with data from the Health Information Systems of the Ministry of Health. Historical sets of indicators related to detection of HIV/AIDS cases and deaths were developed, comparing with national and state data from 2005 to 2015. Also, the cascades of care for PLWHA were elaborated for the municipality between 2013 and 2015. Results: AIDS detection rates of Uruguaiana were higher in comparison to the country and state, the same happened with the mortality and lethality indicators, which varied between 35.1 and 17.7 deaths/100,000 inhabitants and 6.5 and 2.7 deaths/ 100 inhabitants, respectively. The cascades of care for PLWHA showed an increase in individuals diagnosed with HIV in the period (from 1,125 to 1,527). The main gap occurred between the "diagnosed" and "connected" categories, expanding over time ( 78,48 and $43.4 \%$, respectively). There was a low proportion of individuals in the "undetectable viral load" category in the three years, ranging from 32 to $22.9 \%$. Conclusion: Indicators of detection, mortality, and lethality due to HIV / AIDS are high in Uruguaiana, with an increase in the number of people diagnosed with HIV and decrease in their link with health services, suggesting the need for advances in strategies to attract and link PLWHA to the health care network.

Keywords: HIV. Acquired immunodeficiency syndrome. Mortality. Health information systems. Border areas.

'Centro de Ciências, Tecnologias e Saúde, Universidade Federal de Santa Catarina - Araranguá (SC), Brazil.

"Universidade Federal do Pampa - Uruguaiana (RS), Brazil.

Corresponding author: Lucas Pitrez Mocellin. Universidade Federal do Pampa. BR 472, km 585, Caixa Postal 118, CEP: 97501-970, Uruguaiana, RS, Brasil. E-mail: lucasmocellin@unipampa.edu.br

Conflict of interests: nothing to declare - Financial source: none. 
RESUMO: Objetivo: Analisar características e tendência da epidemia de HIV/aids em Uruguaiana, Rio Grande do Sul, entre 2005 e 2015, por meio de indicadores básicos relacionados à infecção e da cascata de cuidado de pessoas vivendo com HIV/aids (PVHA). Métodos: Estudo descritivo realizado com dados dos Sistemas de Informação em Saúde do Ministério da Saúde. Foram elaboradas séries históricas de indicadores relacionados à detecção de casos e óbitos por HIV/aids, comparando com dados nacionais e estaduais de 2005 a 2015. Também foram desenvolvidas as cascatas de cuidado das PVHA para o município entre 2013 e 2015. Resultados: As taxas de detecção de aids de Uruguaiana apresentaram valores mais altos, quando comparadas ao país e ao estado, o mesmo acontecendo com os indicadores de mortalidade e letalidade, que variaram entre 35,1 e 17,7 óbitos/100.000 habitantes e 6,5 e 2,7 óbitos/ 100 habitantes, respectivamente. A cascata de PVHA demonstrou aumento dos indivíduos diagnosticados com HIV no período (de 1.125 para 1.527). O principal gap ocorreu entre as categorias "diagnosticados" e "vinculados", ampliando-se no decorrer do tempo (78, 48 e 43,4\%, respectivamente). Verificou-se baixa proporção de indivíduos na categoria "com carga viral indetectável" nos três anos, variando entre 32 e 22,9\%. Conclusões: Os indicadores de detecção, mortalidade e letalidade por HIV/aids são elevados em Uruguaiana, observando-se aumento do número de pessoas diagnosticadas com HIV e diminuição do vínculo destas com os serviços de saúde, sugerindo a necessidade de avanços em estratégias de captação e vinculação das PVHA à rede de atenção.

Palavras-chave: HIV. Síndrome de imunodeficiência adquirida. Mortalidade. Sistemas de informação em saúde. Áreas de fronteira.

\section{INTRODUCTION}

Official data from the Brazilian Ministry of Health (MH) show that AIDS detection rates dropped from $21.4 / 100,000$, in 2012, to $17.8 / 100,000$ inhabitants, in 2018, showing a decrease of $16.8 \%$ in the period ${ }^{1}$. This decline has been attributed, in large part, to the coping strategies adopted since the end of 2013 by the $\mathrm{MH}$, which expanded the use of antiretrovirals, as well as implemented the "test and treat" strategy $y^{2-4}$.

Although Rio Grande do Sul (RS) was the state with the greatest decrease in the AIDS detection rate between 2008 and 2018 (39.3\%), decreasing from 44.8 to 27.2 cases per 100,000 inhabitants ${ }^{1}$, it has been comprised for over a decade among the units of the federation with the highest incidence of AIDS. Furthermore, it was the state with the highest mortality rate due to the disease in 2018 (7.8 deaths / 100,000 inhabitants), being above the national value (4.4 deaths $/ 100,000$ inhabitants $)^{1}$. In the 2019 composite index ranking, which calculates the detection, mortality and first CD4 cell counts in the last five years, six municipalities with 100,000 inhabitants or more figured in the top 20 positions $^{1}$. In this ranking, the results of the index are presented in descending order, with the first placed having the highest rates, corresponding to the worst results.

Uruguaiana is ranked $52^{\text {nd }}$ in the country in this composite index ${ }^{1}$. In the state, it is part of a group of 14 municipalities that, together, concentrate $70 \%$ of the notifications of HIV/ AIDS and are considered priorities for coping with the disease ${ }^{5,6}$. In the period from 2007 
to 2017, Uruguaiana had the third highest coefficient of gross AIDS mortality in the state (mean of 26.9 per 100,000 inhabitants) ${ }^{7}$. Furthermore, the municipality is located in a free border zone between RS and Argentina and stands out for hosting the largest dry port in Latin America, where a large international flow of vehicles and people circulates ${ }^{8}$. Border regions are characterized as an important source of HIV transmission, representing critical points for drug trafficking, sexual exploitation, and marginalization ${ }^{8}$.

At the end of 2013, the Joint United Nations Program on HIV/AIDS (UNAIDS) defined new international commitments aimed at putting an end to the AIDS epidemic, establishing the 90-90-90 goal: 90\% of people living with HIV and AIDS (PLWHA) are diagnosed, $90 \%$ of diagnosed PLWHA receive antiretroviral therapy (ART), and 90\% of PLWHA on ART achieve viral suppression'. In 2015, Uruguaiana signed the Paris Declaration, committing itself to this strategy of accelerating the response to HIV/ AIDS infection ${ }^{6}$. In order to advance in this direction, it is necessary to study the behavior of the local epidemic, in order to know its specificities and provide more targeted and resolving actions.

In this perspective, the study aimed to analyze characteristics and trends of the HIV/ AIDS epidemic in Uruguaiana, RS, from 2005 to 2015, using basic indicators related to infection and the cascade of continuous care for PLWHA.

\section{METHODS}

Descriptive study carried out with secondary data from the Health Surveillance Secretariat (Secretaria de Vigilância em Saúde - SVS) of the MH. A historical series, from 2005 to 2015, of basic HIV/AIDS indicators and data for Uruguaiana was analyzed.

The municipality is $624 \mathrm{~km}$ from the capital, Porto Alegre, located on the border between Brazil and Argentina, connected to the city of Paso de Los Libres by the international bridge over Uruguai River and only $60 \mathrm{~km}$ from the border with Uruguay ${ }^{10}$. There is an intense flow of Argentines in the municipality, both for shopping in local commerce and for tourism, with Uruguaiana as the main gateway to the Brazilian coast in the summer.

The data in this study were extracted from the electronic platform of the $\mathrm{MH}$ and a contextual analysis of the local situation was conducted ${ }^{11}$, considering the rates of: AIDS detection; detection of AIDS in children under 5 years of age; detection of AIDS in young people between 15 and 24 years of age; detection in HIV-infected pregnant women. The coefficients of gross mortality and lethality due to AIDS were also analyzed. For the last listed indicator, data from the Diseases Notification Information System (Sistema de Informação Agravos de Notificação - SINAN-AIDS) and the Mortality Information System (Sistema de Informação sobre Mortalidade - SIM) available on the $\mathrm{MH}^{12}$ website were also used. AIDS detection indicators in Uruguaiana were compared with those in Brazil and RS, while the mortality and lethality coefficients were compared with the same locations mentioned in addition to the capital, Porto Alegre. 
A cascade of continuous care for PLWHA for the municipality of Uruguaiana was also developed, according to the $\mathrm{MH}^{13}$ protocol. This methodology aims to illustrate the sequence of events related to monitoring the infection that individuals need to advance, from infection to care, to viral suppression ${ }^{14}$. The analysis consists of stratifying the population into specific subgroups, considered as stages of infection monitoring, represented by a graphic divided into six columns:

- First (infected with HIV): estimate of PLWHA;

- Second (diagnosed): diagnosed with HIV;

- Third (connected to health services): within the year, presenting at least one test for CD4 cell count or HIV viral load or an ART discharge);

- Fourth (retained by the health services): within the year, presenting at least two tests for CD4 cell count or HIV viral load or discharge in the last 100 days of the year;

- Thursday (ART in health services): discharge in the last 100 days of the year;

- Sixth (undetectable HIV viral load): being on ART and having an undetectable viral load (less than 50 copies/mL of blood).

Data from 2013 to 2015 were used, obtained from the Laboratory Examination Control System (Sistema de Controle de Exames Laboratoriais - SISCEL), the Medicines Logistics Control System (Sistema de Controle Logístico de Medicamentos - SICLOM), SINAN-AIDS, and SIM.

The first column of the cascade is provided by estimating PLWHA, but there are no studies in the municipal or state scenarios of Rio Grande do Sul that provide the prevalence of individuals with HIV. Therefore, the first column of the cascade was not elaborated, starting the analysis from the column of individuals diagnosed with HIV. Three cascades of PLWHA were developed, one for each year investigated, and comparisons were made between the three years. Two kinds of analysis were adopted:

- having as reference the "diagnosed" column, this being the denominator for calculating the percentage of all other columns;

- calculation of the percentage considering the value of the previous column as the denominator.

The indicators were elaborated and displayed in graphics using the Microsoft Excel software, version 2016. For the rate of AIDS detection cases, stratifications were made regarding age group and cases of vertical transmission (pregnancy). For the construction of the annual PLWHA cascades, the database relationship was initially performed using the Reclink software, version $3.0^{15}$. Then, the SPSS software, version $17.0^{16}$, was used to analyze the data and prepare the cascade graphic. Finally, a comparison was made between the years analyzed for each of the cascade columns by applying the $\chi^{2}$ test. A probability of error (alpha) of $5 \%$ was considered.

This study was developed with public domain data made available by the $\mathrm{MH}$, with no possibility of identifying the subjects, except for the data for the elaboration of the PLWHA cascade, obtained through access to the databases of the State Health Secretariat of Rio 
Grande do Sul (Secretaria Estadual de Saúde do Rio Grande do Sul-SES / RS). Data confidentiality was ensured by signing the confidentiality term and the research was approved by the Research Ethics Committee of Universidade federal do Pampa (opinion number 1.880.377).

\section{RESULTS}

In all analyses involving health indicators, a comparison was made between Uruguaiana, Rio Grande do Sul and Brazil, also considering Porto Alegre in specific analyses. The rate of AIDS detection per 100,000 inhabitants of the municipality, despite fluctuating over the period, showed higher levels than those of the state and the country in almost every year analyzed (Figure 1A). The peak was in 2011, when Uruguaiana had a detection rate of 75 AIDS cases per 100,000 inhabitants, being 1.74 times higher than Rio Grande do Sul and 3.44 times higher than Brazil. The mean values of the indicator, per 100,000 inhabitants, were 52.6 in the municipality, 41.1 in the state, and 20.8 in the country.

Higher values of AIDS detection rate among young people aged 15 to 24 years are observed in the analysis of the municipal sphere (Figure 1B). In the period verified, the mean indicator (cases per 100,000 inhabitants) was 35.7 for Uruguaiana, 23.2 for Rio Grande do Sul, and 11.7 for Brazil. Variations are perceived in the city indicator, being almost 6 times greater than the national in 2008, as well as less than the country and the state in 2010 and 2015. In the population of children under 5 years of age, even greater changes are observed for municipal data (Figure 1C). The mean value of the indicator in the period studied was 12.8 cases for Uruguaiana, 9.1 cases for the state, and 3.4 for Brazil, demonstrating higher levels for the municipality's indicator.

Regarding the detection rate of HIV-infected pregnant women (per 1,000 live births), the worst outlook was also seen for Uruguaiana, which presented higher values than the state and national ones between 2005 and 2014 (Figure 2). In the last two years of the period, there was a downward trend, and in 2015 the value was lower compared to that of Rio Grande do Sul. This indicator means in the period analyzed for Uruguaiana, Rio Grande do Sul, and Brazil were 11.5, 8.6, and 2.2 respectively.

As for the AIDS mortality coefficient, Uruguaiana has a more unfavorable situation than the state and the country (Figure 3A). Whereas, for Brazil, this indicator had a mean of 6.2 deaths / 100,000 inhabitants in the period investigated, Rio Grande do Sul and Uruguaiana showed, respectively, means of 12.9 and 24.0 for the same period. In 2010, the municipality had a higher coefficient than Porto Alegre, as well as an upward trend in the last year analyzed.

The AIDS-related lethality indicator shows a downward trend over time for all investigated locations (Figure 3B). Uruguaiana, with the exception of 2005, has the worst scenario for this coefficient compared to the country, Rio Grande do Sul, and the capital. While the national mean value of 3.2 deaths/100 PLWHA was observed in the analyzed period, Uruguaiana presented a mean of 4.7. In 2015, there is a tendency for this rate to increase in Uruguaiana (3.5 deaths/100 PLWHA). 

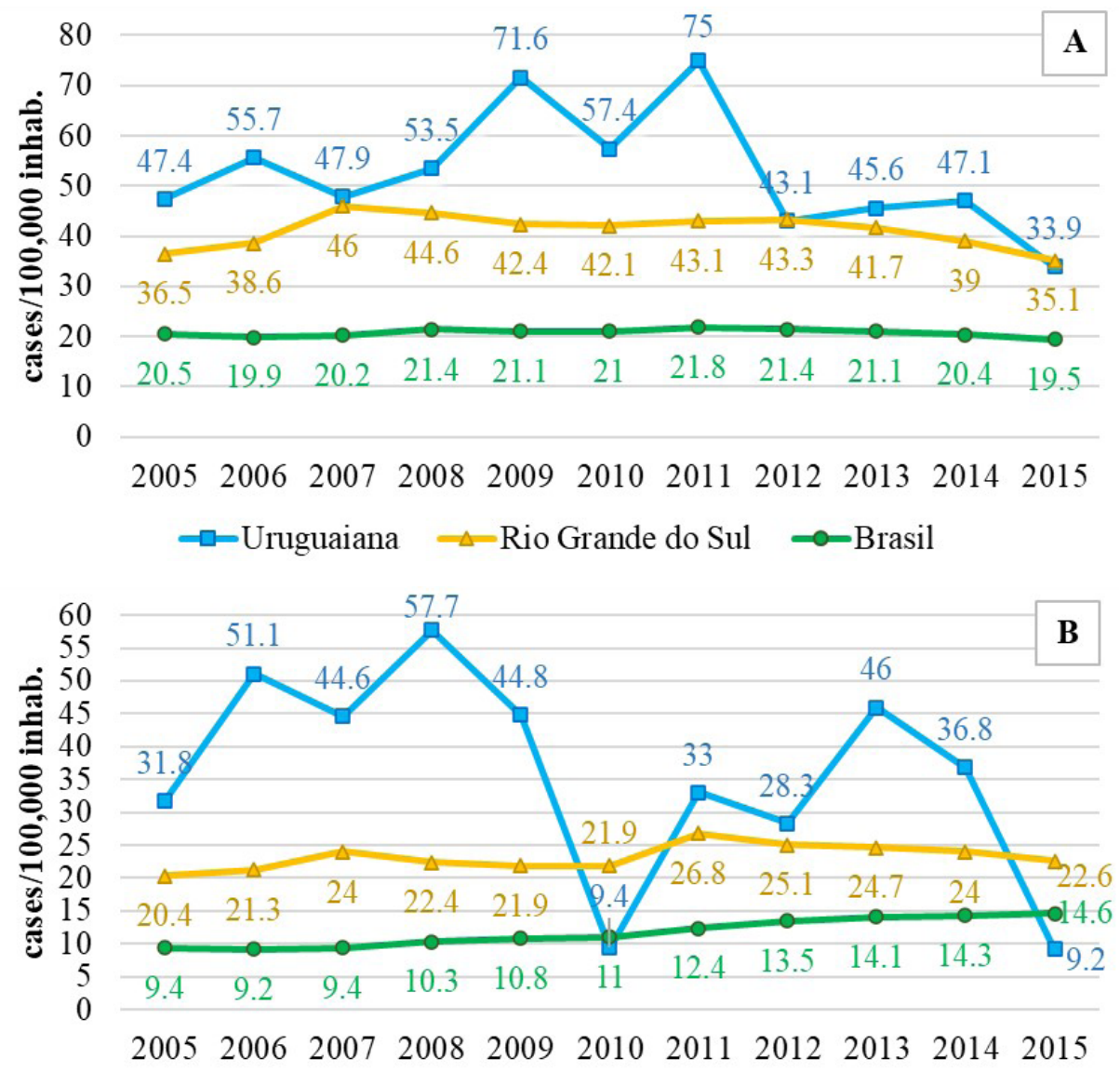

$\rightarrow$-Uruguaiana $\rightarrow-$ Rio Grande do Sul $\multimap-$ Brasil

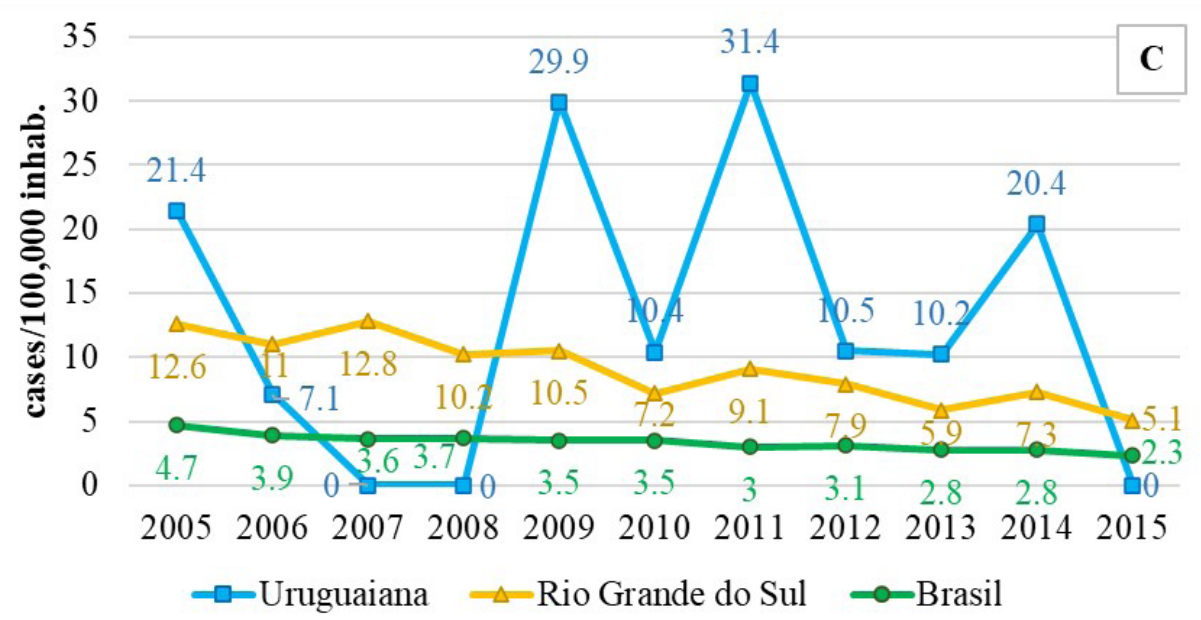

Figure 1. Detection rate (per 100,000 inhabitants) of AIDS cases reported in Uruguaiana, Rio Grande do Sul and Brazil. (A) Total population; (B) population aged 15 to 24 years; (C) population of children under 5 years old. 


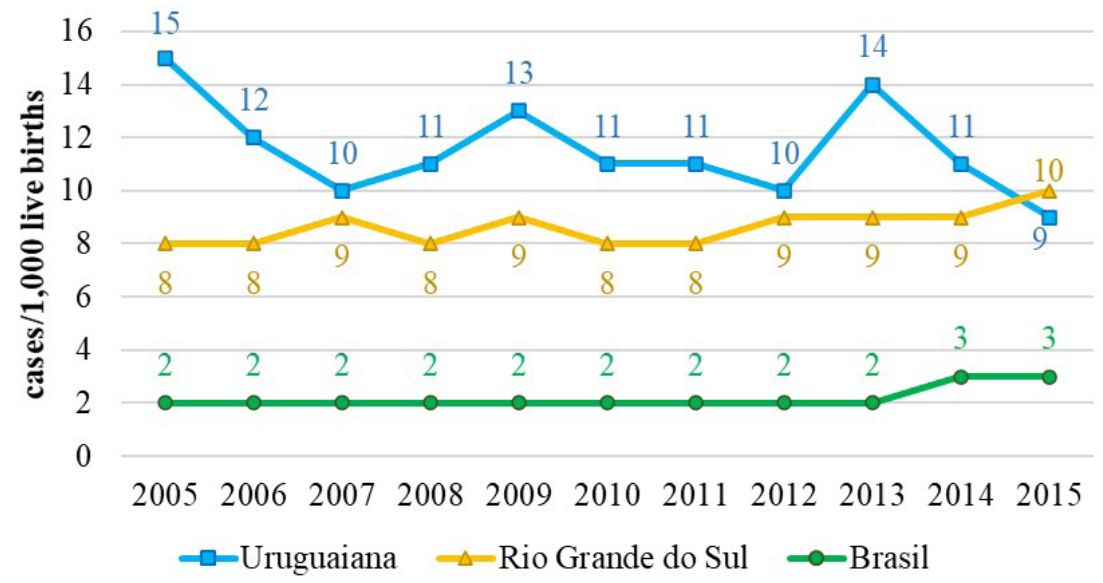

Figure 2. Detection rate in HIV-infected pregnant women (per 1,000 live births), in Uruguaiana, Rio Grande do Sul and Brazil.

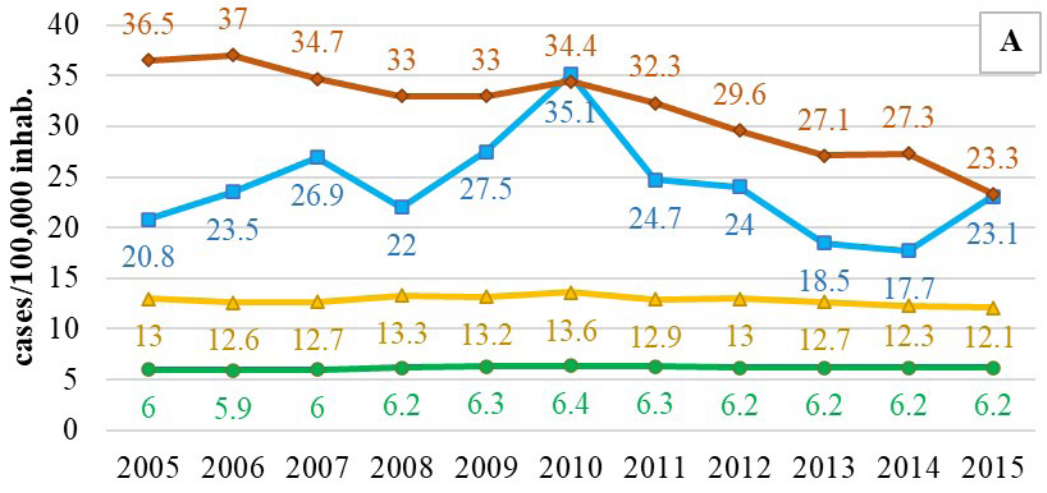

$\rightarrow-$ Uruguaiana $\rightarrow-$ Rio Grande do Sul $\rightarrow$ Brasil $\rightarrow$ Porto Alegre

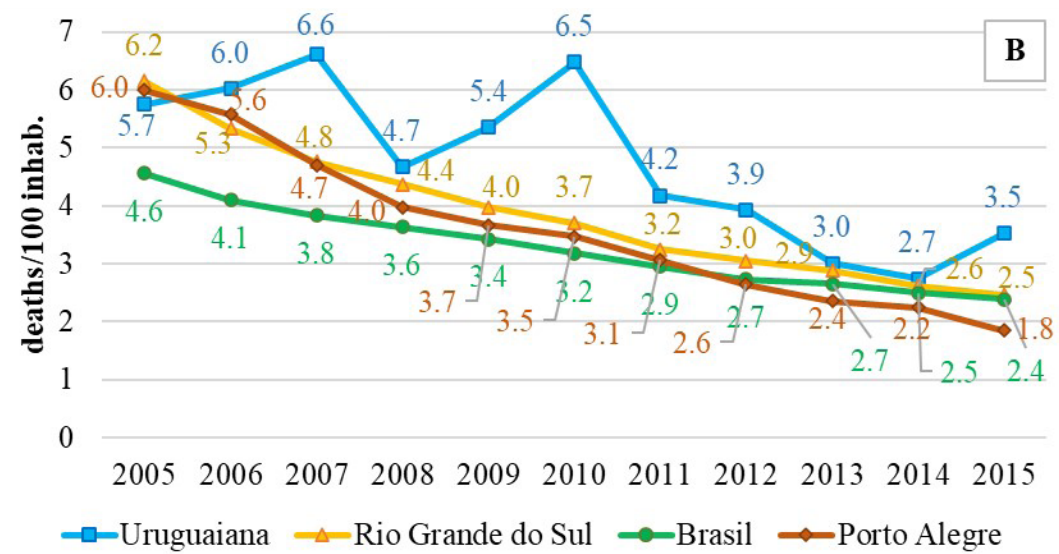

Figure 3. Indicators related to AIDS deaths in Uruguaiana, Porto Alegre, Rio Grande do Sul and Brazil. (A) Gross AIDS mortality rate (per 100,000 inhabitants); (B) AIDS lethality coefficient (per 100 inhabitants). 


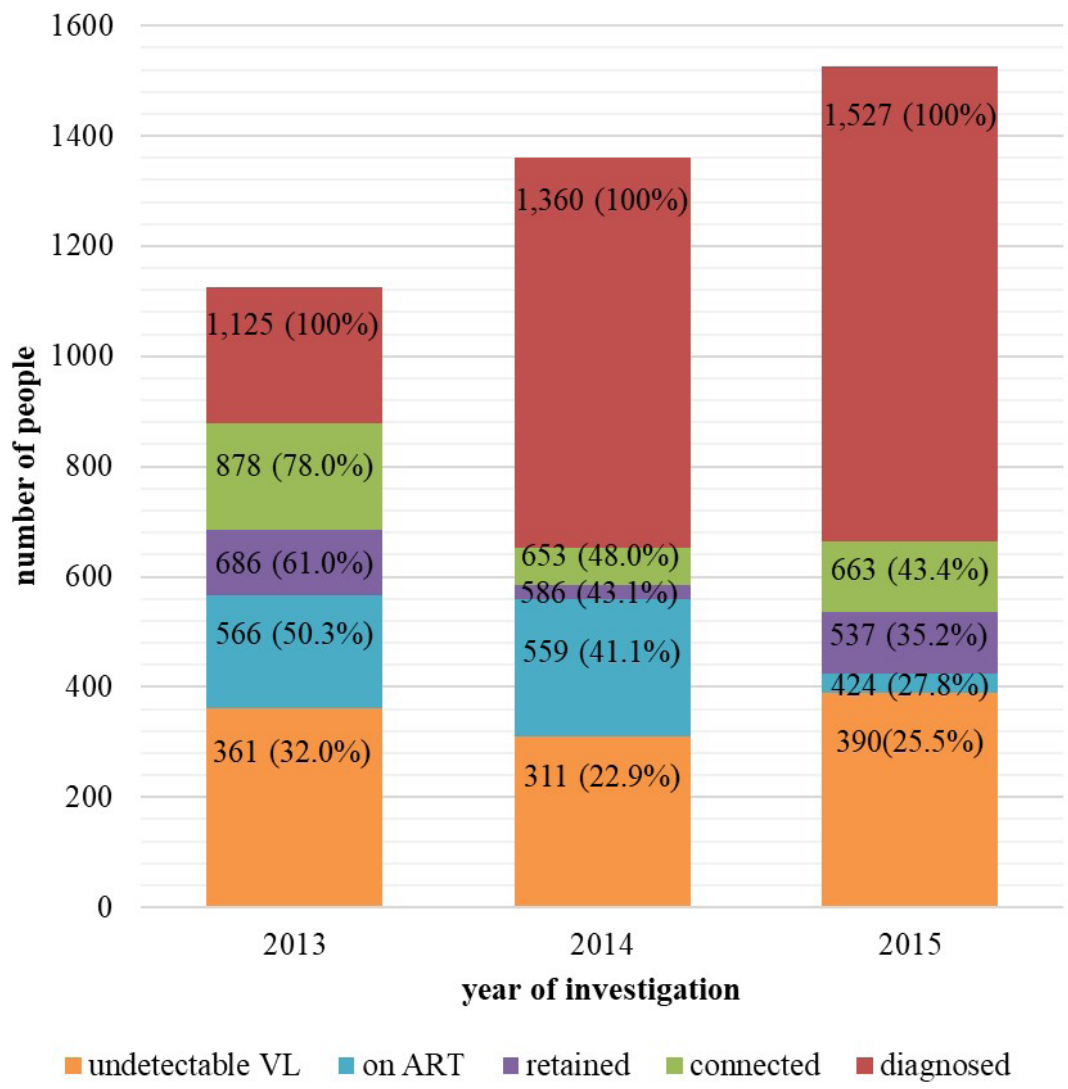

ART: antiretroviral therapy; PLWHA: people living with HIV/AIDS; VL: viral load; Undetectable VL: individuals with less than 50 copies/mL of viral RNA.

Figure 4. Data from the cascade of continuous care for people living with HIV/AIDS in the municipality of Uruguaiana, from 2013 to 2015.

Data from 2013 to 2015 of the cascade of continuous care for PLWHA in Uruguaiana show a gradual increase in the height of the "diagnosed" columns (Figure 4). There is a proportional decrease over the period in the categories "connected to the service", "retained", and "on ART". The main gap of the cascade, which widens over time, is between the "diagnosed" and "connected" columns.

Regarding the comparison of the PLWHA cascades in the three years investigated, in the analysis considering the previous column as the denominator for calculating the percentage, statistically significant differences were observed for the categories "connected" and "with undetectable VL" in all years and for the "retained" and "on ART" categories in the measurements between 2013 and 2014 and between 2014 and 2015 (p < 0.001) (Table 1). In the analysis, taking as a reference the "diagnosed" column, there were statistically significant differences for all categories in the comparison between the three years $(p<0.001)$, except for the category "with undetectable VL", which did not show statistical significance only in the conference between the years 2014 and 2015. 
Table 1. Statistical analysis for comparison between the investigated years of the cascade of continuous care of people living with HIV/AIDS in the municipality of Uruguaiana, from 2013 to 2015.

\begin{tabular}{|l|c|c|c|c|}
\hline \multirow{2}{*}{ Cascade bars of PLWHA } & 2013 & 2014 & 2015 & \multirow{2}{*}{ p-value* } \\
\cline { 2 - 4 } & $\mathrm{n}(\%)$ & $\mathrm{n}(\%)$ & $\mathrm{n}(\%)$ & \\
\hline
\end{tabular}

Analysis considering the previous bar as the denominator for calculating the percentage of bars

\begin{tabular}{l|c|c|c|c|}
\hline Diagnosed & $1,125(100)$ & $1,360(100)$ & $1,527(100)$ & \\
\hline Connected & $878(78)$ & $653(48)$ & $663(43.4)$ & $<0.001^{* *}$ \\
\hline Retained & $686(78.1)$ & $586(89.7)$ & $537(81)$ & $<0.001^{* *}$ \\
\hline On ART & $566(82.5)$ & $559(95.4)$ & $424(79)$ & $<0.001^{* * *}$ \\
\hline Undetectable VL & $361(63.8)$ & $311(55.6)$ & $390(92.0)$ & $<0.001^{* *}$ \\
\hline
\end{tabular}

Analysis considering the bar diagnosed as the denominator for calculating the percentage of bars

\begin{tabular}{l|c|c|c|c}
\hline Retained & $686(61)$ & $586(43.1)$ & $537(35.2)$ & $<0.001^{* *}$ \\
\hline On ART & $566(50.3)$ & $559(41.1)$ & $424(27.8)$ & $<0.001^{* *}$ \\
\hline Undetectable VL & $361(32.1)$ & $311(22.9)$ & $390(25.5)$ & $<0.001^{* * * *}$
\end{tabular}

PLWHA: people living with HIV/AIDS; ART: antiretroviral therapy; VL: viral load; Undetectable VL: individuals with less than 50 copies/mL of viral RNA; * performing the $\chi^{2}$ test to compare bars between years; ** statistically significant values in all comparisons; ${ }^{* * *}$ statistically significant values comparing the years 2013 with 2014 and 2014 with 2015; ****statistically significant values comparing the years 2013 with 2014 and 2013 with 2015.

\section{DISCUSSION}

This study allowed to characterize and analyze the evolution of the HIV / AIDS epidemic in Uruguaiana in recent years. AIDS detection rates for the general population, between 15 and 24 years old, under 5 years old, and in pregnant women were high for the city, compared to Brazil and Rio Grande do Sul; the same trend was observed in the mortality and lethality coefficients, the latter with values above those registered for the country, the state and the capital, Porto Alegre. The findings of the cascade of continuous care for PLWHA show an increase in individuals diagnosed between 2013 and 2015 (1,125 to 1,527), a greater gap in the category of those linked to the health service, and a low percentage of individuals with VL suppression (between 32 and 22.9\%).

The high AIDS detection rates observed in the municipality may be related to weaknesses in the care network and to reflections of structural problems, such as, for example, lack of human resources and continuous technical training of health professionals ${ }^{8}$. The peculiar socioeconomic and demographic characteristics that differentiate border regions from other areas should also be considered, especially due to the presence of the dry port in the city. The border between Uruguaiana and Paso de los Libres (Argentina) was identified as one of the Brazilian border regions with the highest occurrence of AIDS cases due to the intense population flow, which would facilitate the multiplicity of casual partners and unprotected $\operatorname{sex}^{17}$. Some vulnerability situations identified in the municipality in previous 
studies deserve to be highlighted, such as, for example, the concentration of drugs and the sex trade within a declining economic context, gender inequalities and sexual violence, lack of integrated actions between countries, and the difficulty of health services to deal with this complexity ${ }^{8,17,18}$.

The detection rate among young people in the period under investigation was also higher than that of the state and country. The high frequency of detection in young people corroborates another study carried out in a border region ${ }^{17}$ and reflects characteristics of the epidemic, which has been changing over time. Early sexual initiation, multiple partners, unprotected sex, a feeling of invulnerability to the disease ${ }^{19}$, and the existence of social determinants that aggravate the situations of marginalization, prejudice, exclusion, and violence to which many young people are exposed increase their vulnerability and contribute for the spread of infection ${ }^{20}$.

In children under 5 years of age, the detection rate reflects HIV vertical transmission (VT). In Uruguaiana, both this rate and the detection rate in pregnant women are high. Early ART initiation during pregnancy, caesarean delivery, perinatal therapeutic interventions, and non-breastfeeding are measures that, when combined, can reduce VT up to $95 \%{ }^{21,22}$. Failures in the early capture of pregnant women, the inclusion of the partner in prenatal care and the lack of data recorded in the medical records and portfolios of pregnant women can be pointed out as problems that contribute to this situation in the municipality, which in 2015 implemented the Municipal Investigation Committee of HIV/AIDS and Syphilis Vertical Transmission as a means of coping and qualifying surveillance ${ }^{23}$.

The fluctuations observed in the city's AIDS detection rates may be linked to the fragility of the case notification process. A study that analyzed the distribution of HIV/AIDS underreporting in Brazil, between 2012 and 2016, identified high percentages in the western region of Rio Grande do Sul, where Uruguaiana is located (40.7 to $54.5 \%)^{24}$. Similar research in individuals co-infected with tuberculosis / HIV found greater underreporting in inland cities compared to the capital, Recife ${ }^{25}$. Still, the reduced number of AIDS cases each year, mainly for the indicators referring to the age groups of young people and children under 5 years old, can also explain such variations.

Regarding the mortality indicator, there is a worse scenario for Uruguaiana compared to Rio Grande do Sul and Brazil, while for lethality the municipality showed higher values than the country, Rio Grande do Sul, and the capital, Porto Alegre. The coefficients mentioned also varied over time due to the low absolute number of deaths from HIV/AIDS in Uruguaiana. The lethality indicator represents the severity of the health condition and can also inform about the quality of care provided to the patient ${ }^{26}$. High values of lethality for the city demonstrate possible weaknesses in the care network for PLWHA and in the capacity of health services to prevent preventable deaths.

The most recent publications of HIV/AIDS epidemiological bulletins from the $\mathrm{MH}^{1,27-29}$ and the SES / $\mathrm{RS}^{7,30,31}$ present data on the mortality indicator, but do not mention the lethality. Few studies, such as the publication by Barbosa and Costa, which investigated individuals co-infected with HIV/tuberculosis between 2002 and 2011 in the Northeast of Brazil, use the lethality rate to demonstrate the severity and risk of death ${ }^{32}$. 
The cascade of continuous care for PLWHA is usually presented with annual data ${ }^{33,34}$. However, this analysis presented a longitudinal cut, elaborated using stacked bars for each year, as performed by the study by Nosyk et al., who developed the cascade of PLWHA residing in British Columbia, Canada, between 1996 and 2011 $1^{35}$. This form of analysis allows characterizing changes over time in relation to the engagement of individuals in health care $^{35}$. The findings of the present study show that there was an increase in the number of diagnosed individuals, initially with 1,125 subjects in 2013, 1,360 in 2014, and 1,527 in 2015. This fact is possibly due to the increase in access to diagnosis over the period, since the availability of rapid HIV tests in Family Health Strategies in Uruguaiana started in July 2013. The same trend was observed in the study referred to ${ }^{35}$.

The largest gap was found between the categories diagnosed and connected to the health service, similar to that observed in the cascade of PLWHA in Rio Grande do Sul, in $2013^{34}$, which suggests that the advances observed in relation to the diagnosis of HIV were not accompanied by a strategy to expand patient access to health services in Uruguaiana. Still, it is noteworthy the low percentage of the category individuals with undetectable VL $(32,22.9$, and 25.5\%, respectively, for 2013, 2014, and 2015). A research in Canada in 2011 showed that the population with suppression of viral load was over $60 \%$ among diagnosed individuals ${ }^{36}$.

Checks between the cascades of PLWHA in Uruguaiana and the achievement of the goal 90-90-90 were carried out, similar to the research carried out with the PLWHA population in Korea in $2018^{37}$. It was observed that, in relation to the treatment target, only 50.3, 41.1 , and $27.8 \%$ were on ART in the years 2013 , 2014, and 2015, respectively. It is worth mentioning the implementation by the $\mathrm{MH}$, in 2013, of the "test and treat" strategy, which generated expansion in relation to the number of individuals requiring $\mathrm{ART}^{2,3}$. Therefore, it was expected that, as of 2014, the number of patients on ART will increase over time. Controversially, our results show a downward trend, showing weaknesses in the care for patients with HIV and distancing from the goal.

As for the goal involving the suppression of viral load, it is clear that the percentages were $63.8,55.6$, and $92 \%$ for 2013, 2014, and 2015, respectively. Despite observing the achievement of the target in 2015, a more prolonged analysis is still necessary to verify the continuity of this result. A study developed with patients seen at a university hospital in Paraná, between 2012 and 2015, demonstrated that there is still considerable distance to reach the goals $90-90-90^{38}$, similarly to the results of this study.

With regard to research limitations, the use of secondary data should be considered. Despite this, the probabilistic relationship of the different databases was a strategy implemented in the present study, aiming to minimize weaknesses inherent to the use of different sources of information. It is also worth mentioning that the first column of the cascade was removed from our analysis, which did not allow using this column as a denominator for calculating the percentage of subsequent columns or verifying the reach of the first 90 of the UNAIDS target ${ }^{9}$. However, since there are no studies that allow us to use a reliable estimate of PLWHA in the local or state scenario, the cascades were created from the second bar, which was constructed with information from SINAN. 
In summary, there are high values of indicators for the detection of AIDS, mortality, and lethality in Uruguaiana, compared to Rio Grande do Sul and Brazil. The cascade of PLWHA shows important differences between 2013 and 2015, with an increase in the number of people diagnosed and a reduction in the percentage of categories related to attachment, a reduction in the percentage of categories "on ART", "retained" and "connected", being in the latter the largest gap observed. The number of people who manage to achieve an undetectable viral load of HIV is still low.

The findings of this study allow us to raise hypotheses about vulnerabilities in the care network for PLWHA in Uruguaiana, with important limitations related to the care provided to patients, focusing on the avoidability of deaths from AIDS. The implantation of the CD4+ T lymphocyte counting laboratory and quantification of HIV viral load in the municipality and the creation of the Municipal AIDS Mortality Investigation Committee, in 2017, were important local strategies to face the epidemic. However, efforts by managers aimed at monitoring and linking PLWHA to health services are still needed. The performance of studies that follow the trend of the indicators and investigate the quality of care is essential to identify weaknesses and assess the evolution of the municipality toward reaching the 90-90-90 goal.

\section{REFERENCES}

1. Brasil. Ministério da Saúde. Secretaria de Vigilância em Saúde. Boletim Epidemiológico de HIV e Aids [Internet]. Brasil: Ministério da Saúde; 2019 [accessed on Jun. 2020]. Available at: http:/ / www.aids.gov.br/pt-br/ pub/2019/boletim-epidemiologico-de-hivaids-2019

2. Brasil. Ministério da Saúde. Secretaria de Vigilância em Saúde. Departamento de DST, Aids e Hepatites Virais. Protocolo clínico e diretrizes terapêuticas para manejo da infecção pelo HIV em crianças e adolescentes [Internet]. Brasil: Ministério da Saúde; 2014 [accessed on May 25, 2018]. Available at: http: / / www.aids.gov. $\mathrm{br} / \mathrm{pt}-\mathrm{br} / \mathrm{pub} / 2014$ / protocolo-clinico-e-diretrizesterapeuticas-para-manejo-da-infeccao-pelo-hiv-emcriancas-e

3. Brasil. Ministério da Saúde. Secretaria de Vigilância em Saúde. Departamento de Vigilância, Prevenção e Controle das Infecções Sexualmente Transmissíveis, do HIV/Aids e das Hepatites Virais. Protocolo Clínico e Diretrizes Terapêuticas para Manejo da Infecção pelo HIV em Adultos [Internet]. Brasília: Ministério da Saúde; 2018 [accessed on Jul. 23, 2020]. Available at: http://www.aids.gov.br/system/ tdf/pub/2016/64484/pcdt_adulto_12_2018_web. pdf file $=1 \&$ type $=$ node $\&$ id $=64484 \&$ force $=1$

4. UNAIDS. Joint United Nations Programme on HIV/AIDS. 90-90-90. Uma meta ambiciosa de tratamento para contribuir para o fim da epidemia de AIDS [Internet]. UNAIDS; 2015 [accessed on Oct. 14, 2020]. Available at: https:/ / unaids.org.br/ wp-content/uploads/2015/11/2015_11_20_UNAIDS_ TRATAMENTO_META_PT_v4_GB.pdf

5. Rio Grande do Sul. Secretaria Estadual da Saúde. Coordenação Estadual de DST/Aids. Coordenação Estadual de Atenção Básica. Linha de Cuidado para Pessoas Vivendo com HIV / Aids (PVHA) e outras DST [Internet]. 2014 [accessed on Jun. 2, 2020]. Available at: http:/ / observatorioaids.saude.rs.gov.br/wp-content/ uploads / 2019/06/Linha-de-Cuidado-E-book.pdf

6. UNAIDS Brasil. Programa Conjunto das Nações Unidas para o HIV e AIDS - Brasil. Adesão de cidade à Declaração de Paris já beneficia $35 \mathrm{mi}$ de brasileiras e brasileiros [Internet]. UNAIDS Brasil; 2016 [accessed on Jun. 6, 2020]. Available at: http:// unaids.org. br/2016/03/adesao-de-cidades-a-declaracao-de-parisja-beneficia-35-mi-de-brasileiras-e-brasileiros-hiv-aids / 7. Rio Grande do Sul. Secretaria de Estado da Saúde. Departamento de Ações em Saúde. Seção Estadual de Controle de DST / Aids. Boletim Epidemiológico: HIV/ Aids [Internet]. Rio Grande do Sul: Secretaria de Estado da Saúde; 2018 [accessed on Jun. 2, 2020]. Available at: https: / /www.saude.gov.br/images/pdf/2019/ novembro/29/Boletim-Ist-Aids-2019-especial-web.pdf 
8. Brasil. Ministério da Saúde. Secretaria Executiva. Coordenação Nacional de DST e Aids. A Aids nas fronteiras do Brasil [Internet]. Brasil: Ministério da Saúde; 2003 [accessed on Jun. 4, 2020]. Available at: http: / / bvsms.saude.gov.br/bvs/publicacoes/aids_ fronteira.pdf

9. UNAIDS. Joint United Nations Programme on HIV/ AIDS. Fast-Track Ending the AIDS epidemic by 2030 [Internet]. UNAIDS; 2014 [accessed on Jun. 6, 2020]. Available at: https://bit.ly/1uu2dCA

10. Instituto Brasileiro de Geografia e Estatística (IBGE). Censo Demográfico [Internet]. Brasil: Governo Federal do Brasil; 2019 [accessed on Apr. 30, 2020]. Available at: https: / cidades.ibge.gov.br/brasil/rs/uruguaiana/ panorama

11. Brasil. Indicadores e Dados Básicos do HIV/aids nos Municípios Brasileiros [Internet]. Brasil; 2018 [accessed on Jun. 5, 2020]. Available at: http:// indicadores.aids.gov.br/

12. Brasil. Informações de Saúde (TABNET) [Internet]. 2008 [accessed on Jun. 7, 2020]. Available at: http: / / www2.datasus.gov.br/DATASUS/index.php?area $=02$

13. Brasil. Ministério da Saúde. Secretaria de Vigilância em Saúde. Departamento de Vigilância Prevenção e Controle das IST do HIV/Aids e das Hepatites Virais. Manual Técnico de Elaboração da Cascata de Cuidado Contínuo do HIV [Internet]. Brasil: Ministério da Saúde; 2017 [acessed on May 8, 2018]. Available at: http: / / www.aids.gov.br/pt-br/pub/2017/ manualtecnico-de-elaboracao-da-cascata-de-cuidado-continuo

14. MacCarthy S, Hoffmann M, Ferguson L, Nunn A, Irvin R, Bangsberg D, et al. The HIV care cascade: models, measures and moving forward. J Int AIDS Soc 2015; 18(1): 19395. https:/ / doi.org/10.7448/ias.18.1.19395

15. Camargo Jr. KR, Coeli CM. Reclink: aplicativo para o relacionamento de bases de dados, implementando o método probabilistic record linkage. Cad Saúde Pública [Internet]. 2000 [accessed on Jun. 19, 2020]; 16(2): 439-47. Available at: http://www.scielo. $\mathrm{br} /$ scielo.php?script $=$ sci_arttext $\&$ pid $=$ S0102-

311X2000000200014\&lng=en https:/ / doi.org/10.1590/ S0102-311X2000000200014

16. SPSS Inc. Released 2008. SPSS Statistics for Windows, Version 17.0. Chicago: SPSS Inc.; 2008.

17. Mombelli MA, Barreto MS, Arruda GO, Marcon SS. Epidemia da aids em tríplice fronteira: subsídios para a atuação profissional. Rev Bras Enferm 2015; 68(3): 429-37. https://doi. org/10.1590/0034-7167.2015680308i

18. Rodrigues-Júnior AL, Castilho EA. AIDS e doenças oportunistas transmissíveis na faixa de fronteira Brasileira. Rev Soc Bras Med Trop 2010; 43(5): 542-7. https: / / doi.org/10.1590/S0037-86822010000500014
19. Fontanella BJ, Gomes R. Prevenção da AIDS no período de iniciação sexual: aspectos da dimensão simbólica das condutas de homens jovens. Ciên Saúde Colet 2012; 17(12): 3311-22. https:/ / doi.org/10.1590/ S1413-81232012001200016

20. Maksud I, Fernandes NM, Filgueiras SL. Tecnologias de Prevenção do HIV e desafios para os serviços de saúde. Rev Bras Epidemiol 2015; 18(Supl. 1): 104-19. https: / doi.org/10.1590/1809-4503201500050008

21. Nesheim S, Taylor A, Lampe MA, Kilmarx PH, Harris LF, Whitmore S, et al. A Framework for elimination of perinatal transmission of HIV in the United States. Pediatrics 2012; 130(4): 738-44. https:/ / doi. org/10.1542/peds.2012-0194

22. Luzuriaga K, Mofenson LM. Challenges in the elimination of pediatric HIV-1 infection. N Engl J Med 2016; 374: 761-70. http:/ / doi.org/10.1056/NEJMra1505256

23. Rio Grande do Sul. Secretaria da Saúde. Departamento de Ações em Saúde. Cooperação Interfederativa HIV/Aids. Cooperação Interfederativa HIV/Aids: compartilhando êxitos [Internet]. Rio Grande do Sul: Secretaria da Saúde; 2017 [accessed on Jun. 6, 2020]. Available at: http:/ / observatorioaids.saude.rs.gov.br/ wp-content/uploads/2017/03/Livro-Compartilhando\%C3\%8Axitos.pdf

24. Coelho RA. Estudo da distribuição da subnotificação do HIV/aids no Brasil, 2012 a 2016 [dissertação]. Brasília: Universidade de Brasília; 2019.

25. Santos ML, Coeli CM, Batista JAL, Braga MC, Albuquerque MFPM. Fatores associados à subnotificação de tuberculose com base no Sinan Aids e Sinan Tuberculose. Rev Bras Epidemiol [Internet] 2018 [accessed on Oct. 19, 2020]; 21: e180019. Available at: https: / / doi.org/10.1590/1980-549720180019

26. Merchán-Hamann E, Tauil PL, Costa MP. Terminologia das medidas e indicadores em epidemiologia: subsídios para uma possível padronização da nomenclatura. Inf Epidemiol Sus 2000; 9(4): 276-84. https: / / doi. org/10.5123/S0104-16732000000400006

27. Brasil. Ministério da Saúde. Secretaria de Vigilância em Saúde. Departamento de Vigilância Prevenção e Controle das IST do HIV / Aids e das Hepatites Virais. Boletim Epidemiológico HIV Aids 2018 [Internet]. Brasil: Ministério da Saúde; 2018 [accessed on Jun. 2, 2020]. Available at: http://www.aids.gov.br/pt-br/ pub/2018/boletim-epidemiologico-hivaids-2018

28. Brasil. Ministério da Saúde. Secretaria de Vigilância em Saúde. Departamento de Vigilância Prevenção e Controle das IST do HIV/Aids e das Hepatites Virais. Boletim Epidemiológico HIV Aids 2017 [Internet]. Brasil: Ministério da Saúde; 2017 [accessed on Jun. 2, 2020]. Available at: http://www.aids.gov.br/pt-br/ pub/2017/boletim-epidemiologico-hivaids-2017 
29. Brasil. Ministério da Saúde. Secretaria de Vigilância em Saúde. Departamento de Vigilância Prevenção e Controle das IST do HIV/Aids e das Hepatites Virais. Boletim Epidemiológico HIV Aids 2016 [Internet]. Brasil: Ministério da Saúde; 2016 [accessed on Jun. 2, 2020]. Available at: http://www.aids.gov.br/pt-br/ pub/2016/boletim-epidemiologico-de-aids-2016

30. Rio Grande do Sul. Secretaria de Estado da Saúde. Boletim epidemiológico HIV/ AIDS 2017. [Internet]. Rio Grande do Sul: Secretaria de Estado da Saúde; 2017 [accessed on Jun. 6, 2020]. Available at: http:/ / observatorioaids.saude.rs.gov.br/wp-content/ uploads / 2019/04/Boletim-Epidemiol\%C3\%B3gicoHIVAids-2017.pdf

31. Rio Grande do Sul. Secretaria de Estado da Saúde. Boletim epidemiológico HIV/aids 2016 [Internet]. Rio Grande do Sul: Secretaria de Estado da Saúde; 2016 [accessed on Jun. 6, 2020]. Available at: https://saude.rs.gov.br/ upload/arquivos/carga20170416/27141658-boletimepidemiologico-rs-hiv-aids-2017-compressed.pdf

32. Barbosa IR, Costa IDCC. Estudo epidemiológico da coinfecção tuberculose-HIV no nordeste do Brasil. Rev Patol Trop 2014; 43(1): 27-38. https: / / doi.org/10.5216/ rpt.v43i1.29369

33. Brasil. Ministério da Saúde. Secretaria de Vigilância em Saúde. Departamento de Vigilância Prevenção e Controle das IST do HIV/Aids e das Hepatites Virais. Boletim Epidemiológico HIV Aids 2015 [Internet]. Brasil: Ministério da Saúde; 2015 [accessed on Jun. 5, 2020]. Available at: http://www.aids.gov.br/pt-br/ pub/2015/boletim-epidemiologico-hivaids-2015

34. Rio Grande do Sul. Secretaria de Estado da Saúde. Boletim Epidemiológico HIV/aids e Sífilis 2015. [Internet]. Rio Grande do Sul: Secretaria de Estado da Saúde; 2015 [accessed on Jun. 6, 2020]. Available at: http:/ / observatorioaids.saude.rs.gov.br/wp-content/ uploads / 2019/04/Boletim-Epidemiol\%C3\%B3gicoHIVAids-e-S\%C3\%ADfilis-2015.pdf

35. Nosyk B, Montaner JSG, Colley G, Lima VD, Chan $\mathrm{K}$, Heath K, et al. The cascade of HIV care in British Columbia, Canada, 1996-2011: a populationbased retrospective cohort study. Lancet Infect Dis 2014; 14(1): 40-9. https:// doi.org/10.1016\% 2FS1473-3099(13)70254-8

36. Lourenço L, Colley G, Nosyk B, Shopin D, Montaner JSG, Lima VD, et al. High levels of heterogeneity in the HIV cascade of care across different population subgroups in British Columbia, Canada. PLoS One 2014; 9(12): e115277. https:/ / doi.org/10.1371/journal. pone. 0115277

37. Choi JY. The HIV Care Cascade in Korea: Status of UNAIDS 90-90-90 Targets. J Korean Med Sci 2020; 35(6): e55. https: / / doi.org/10.3346/jkms.2020.35.e55

38. Vogler IH, Alfieri DF, Gianjacomo HDB, Almeida ERD, Reiche EMV. Cascade of care for people living with HIV infection in Southern Brazil: results from a public health network. Cad Saúde Pública 2018; 34(12): e00009718. https: / / doi.org/10.1590/0102-311x00009718

\section{Received on: $08 / 20 / 2020$ \\ Reviewed on: 11/27/2020 \\ Accepted on: 11/30/2020 \\ Preprint on: 12/14/2020}

\begin{abstract}
Authors' contribution: R.S.D. and L.P.S.M. participated in all phases of the study, from planning, analysis, interpretation and discussion of results, writing and final review of the article; H.G. participated in data analysis, interpretation of results, and final review of the article.
\end{abstract}

